Riga Teacher Training and Educational Management Academy, Child Language Research Center, Latvia

\title{
Children's Language Improvement Possibilities
}

\section{Abstract}

Development and improvement of children's language generally takes place on three levels: the first level - parents, the influence of language in the family, the second level - the influence of language at school (pre-school and primary school), and the third level - the influence of language in the environment (the yard, the street or the local area). A child exists in a world full of words. It intuitively more or less understands and applies the most frequently heard words and expressions in the everyday speech. A child's language is largely influenced by the family, teachers, as well as friends and other people that are considered by the child to be its authority. All of these sources play a certain role in the processes of language acquisition and development of speech culture. Linguistic communication is also closely associated with learning the accepted norms of behaviour, use of means of language expression in particular communication situations, their appropriate or inappropriate use. It is known that a wide range of linguistic means, a rich vocabulary, knowledge of the meanings and function peculiarities of words are required for the expression of thoughts, feelings and judgements, Enrichment of vocabulary is closely tied with the intellectual growth of a child. There are diverse ways of enriching their lexicon and evoking interest in words. Imperfections in children's vocabulary have various reasons: the inability of parents to cultivate the language of their children in the pre-school age, insufficient performance of teachers in identifying the value of words, lack of unified requirements in the area of speech culture cultivation for teachers of various lessons (kindergarten) and of all subjects (primary school).

Childhood is both the fundament of life and language learning. Only by fully acquiring one's native language and by developing speech can a person become part of the cultural life in his or her native country and exist as a creative personality, qualitatively perform tasks at work and successfully engage in communication.

Key words Child's language, pre-school, primary school, language improvement, language enrichment.

\section{Introduction}

Several European countries have developed pre-school education programmes that devote large attention to the development of child's language (See Table 1.: Graudin,a, 2004,163). 


\begin{tabular}{|c|c|}
\hline $\begin{array}{l}\text { Belgium: } \\
\text { Psycho-motor activities } \\
\text { Plastic arts } \\
\text { Language } \\
\text { Mathematical activities } \\
\text { Musical activities } \\
\text { Scientific activities } \\
\end{array}$ & $\begin{array}{l}\text { France: } \\
\text { Physical education } \\
\text { Scientific and technical activities } \\
\text { Communication and oral and written } \\
\text { expression } \\
\text { Artistic and aesthetic activities }\end{array}$ \\
\hline $\begin{array}{l}\text { Germany: } \\
\text { Independence and socialisation } \\
\text { Play and other appropriate activities } \\
\text { Development of physical, intellectual, } \\
\text { emotional and social skills } \\
\text { Introduction to organised daily and basic } \\
\text { principles of hygiene }\end{array}$ & $\begin{array}{l}\text { Greece: } \\
\text { Psycho-motor activities [space, time] } \\
\text { Physical education } \\
\text { Artistic activities } \\
\text { Technology and environmental studies } \\
\text { Preparation for reading and number skills } \\
\text { Social and religious activities }\end{array}$ \\
\hline $\begin{array}{l}\text { Spain: } \\
\text { Personal identity and autonomy } \\
\text { Physical and social environment } \\
\text { Communication and representation }\end{array}$ & $\begin{array}{l}\text { Luxembourg: } \\
\text { Physical activities } \\
\text { Musical activities } \\
\text { Artistic activities } \\
\text { Logic and mathematics } \\
\text { Language exercises } \\
\text { Introduction to science }\end{array}$ \\
\hline $\begin{array}{l}\text { Ireland: } \\
\text { Religion } \\
\text { Irish } \\
\text { English } \\
\text { Mathematics } \\
\text { Environmental studies } \\
\text { Plastic arts } \\
\text { Music } \\
\text { Sport } \\
\end{array}$ & $\begin{array}{l}\text { Italy: } \\
\text { Body and movement } \\
\text { Speech and language } \\
\text { Space, order, shape, clothing } \\
\text { Time, feeling of rhythm } \\
\text { Nature } \\
\text { Message } \\
\text { Etiquette and environment } \\
\text { The self and others }\end{array}$ \\
\hline $\begin{array}{l}\text { Scotland: } \\
\text { Psychomotoric activities } \\
\text { Physical education } \\
\text { Artistic activities } \\
\text { (Preparation for reading and writing) }\end{array}$ & $\begin{array}{l}\text { Portugal: } \\
\text { Movement } \\
\text { Teaching of mother tongue } \\
\text { Drama and music } \\
\text { Plastic arts } \\
\text { Mathematics }\end{array}$ \\
\hline $\begin{array}{l}\text { Denmark: } \\
\text { Undefined }\end{array}$ & $\begin{array}{l}\text { The Netherlands: } \\
\text { Undefined }\end{array}$ \\
\hline $\begin{array}{l}\text { England and Wales } \\
\text { Artistic activities } \\
\text { Social activity } \\
\text { Language activities } \\
\text { Mathematics } \\
\text { Civil rights and duties }\end{array}$ & $\begin{array}{l}\text { Physical activities } \\
\text { Science } \\
\text { Technology } \\
\text { Religion }\end{array}$ \\
\hline
\end{tabular}


Development of a democratic society of Latvia, its inclusion into the EU, social integration processes and stabilization of a free market economy have changed the emphasis in the education contents of the new generation. New subject standards and educational model programmes have been adopted in order for the child to successfully integrate into the society. More attention is given to the complex development of emotional formation, communication, speaking, reading and writing skills, the improvement of speaking, reading and writing culture, as well as the development of mathematical understanding skills, performing arts activities, physical development and vision and hearing skill development. Educational contents include game as an integral component of childhood, which is used for the intellectual development of preschool aged children. It is important to develop "child's figurative thinking through sensuous cognition and thus speech, therefore a child should be engaged in exciting activities." (Jurgena, 2002).

\section{Aim of the study}

This article has been produced as part of the RTTEMA Child Language Research Centre grant by the Latvian Council of Science and is meant for introducing readers to the possibilities of children's language improvement. Given that the basic aim of the study was to clarify in what ways children's language is enriched in the preschool and primary school, our task was to develop interview and survey questions to describe the data obtained as a result of interviews and surveys.

\section{Materials and methods}

The study was conducted at the Jūrmala city kindergarten "Taurenītis" and Pumpuru secondary school by engaging preschool and primary school teachers as well as parents.

\section{Results and discussion}

In the preschool age a child learns the language through a process of imitation and that plays an important role in the child's intellectual and cultural development. In their speech children often imitate what they pick up from the environment, which unfortunately often includes barbarism, jargon and other words of nonliterary speech. In today's society there is impoverishment of native language, which manifests itself not just in the speech of teenagers, young adults and certain social groups, but also in the means of mass communication (Freiberga, 2006, 133). Certainly, corrupt, impoverished language that is heard at every turn may have significant impact upon a child's language development, therefore the emphasis in the cultivation and enrichment of language of the young generation should be put on the requirement of the adults (and teachers in particular) to develop correct and well-mastered speech and writing skills. The task of the teacher-accompanied by his or her enthusiasm and pedagogical talent - is to manage the subtle and time-consuming process of child's language cultivation and improvement. It 
is the teacher of the native language, who popularizes the norms suggested by linguists at school, teaches to use language means according to the needs of communication, educate the children in the spirit of honour to the native language and encourage the use of cultivated language. Their favoured words, expressions and pronunciation are imitated by pupils consciously (mostly pupils from younger grades) or unconsciously; therefore the speech behaviour of each teacher should be worth the imitation (Kuzina, 2005). It is important for the school to explain the questions of ethics and aesthetics, without neglecting the fact that in their communication pupils use means of expression that are inappropriate for a cultured person - various plain language words that are offensive to human dignity as well as words of argot. If from early childhood we succeed in creating awareness of the beautiful and the ugly in language and of the necessity to cultivate and develop speech as a significant component of personality and its expression, then we will create a basis for an active attitude towards language among the pupils' peers and in wider society. To take care of children's speech is to take care of their thinking culture, the level of mind and the emotional world, therefore the language culture of pupils must not be left without deeper attention.

Language culture skills must be developed prior to school age, therefore kindergarten and younger grade school programmes should foresee a place for language culture questions, linking topics related to phonetics, grammar and stylistics with cultivation of speech.

Language culture questions are also being considered within the national language programme "Guidelines of the State Language Policy (2005 - 2014)", in which it is stated: "To facilitate qualitative acquisition of Latvian language both among the Latvians and representatives of minorities in Latvia, to improve language culture by facilitating the spread of the reading tradition and it being rooted into the society, particularly among children and young adults".

Child's language researchers (V.Rūke-Draviña, D.Markus and others) believe that the first 4-5 years of life constitute the most significant stage of children's language development. A normally developed child at this age has already developed its language and along with that various notions and perception of the surrounding world. The child develops communication skills, which are further advanced by games and other lessons of various kinds. By listening to fairy tales, stories and poems read to them or told by parents and teachers, the child acquires such notions as kind-heartedness, honesty, diligence and comprehends the corresponding opposites cruelty, dishonesty, laziness. We perceive a child's language not only as a more primitive form of language, but also as a reflection of a childlike way of thinking - a simple, clear, kind and sometimes amusing way with a purposeful wish to explore the world, which we live in (Markus, 2006, 309). Oftentimes even wrong use of language by small children may be absolutely lovely, for instance „Pasveicini

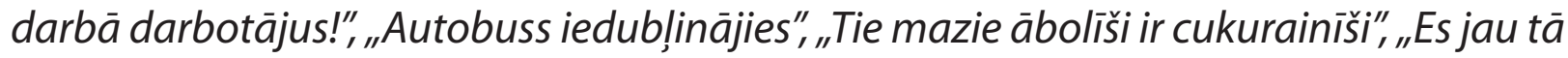


gribètu teikt, bet man tā nesakās" etc. By trying to imitate adults, the child unleashes imagination and possibilities of speech. Child's individuality, world of associations and communication experience develops based on the native language.

For the child to be able to tell about a certain event, an experience or an incident, to share its thoughts and feelings, the child must have a rich enough vocabulary, because that is what a child's communication with others depends on. The speaking abilities of the child is to be cultivated and improved through regular, purposeful and planned work. In the preschool children obtain an insight into the linguistic means of expression used in fairy tales, stories and other texts, but in the primary school they improve their speaking skills and begin conscious learning, acquire reading and writing skills. The reading skill gives children an opportunity to significantly enrich language, the volume of vocabulary, by acquiring words from different lexical strata and to gradually develop an understanding of language as a powerful means of influence. By reading books, a child gets to know a text, its structure, elements, the styles and figurative means of expression used by different authors. It is important to be in dialogue with children both in the study process and at home and discuss what has been read, how the child has understood the text, how the child perceives and assesses the events and the people described in it. It is equally important to pay attention of the young reader to the language used by the author, and to encourage the child to consciously, purposefully and adequately make use of the figurative means of expression and idioms found in the author's work. "A book, by providing an opportunity to get to know its contents and form in a deep and detailed way, is the best way of teaching to speak and to write in a correct language, to think and to formulate own thoughts, to become aware of and to acquire the richness of language, to feel its beauty. All of that is necessary in order to explore the world and to find oneself in it" (Veidemane, 1987, 48).

As mentioned before, games are one of the most effective means for the language development of pre-school aged children. The emphasis in each game is on the sensory-motor aspect, as well as the emotional (wanting to be active), the cognitive (activates processes of cognition) and the social aspects (child-child and child-adult collaboration). Given that in games use is made of objects of various sizes and forms (an oval, a circle, a triangle a rectangle etc.) and objects in various colours, the child develops its sensory system through playing, gets to know colours and forms of objects, their characteristics (for instance, round, smooth, hard, soft etc.), learns to tell differences and similarities between objects, acquires various techniques, learns to estimate own strengths and weaknesses. Through games the child must not only take up the skill to define objects and to distinguish between particular traits and characteristics, but also to express them in words. Through games with various contents children learn the names of objects, actions etc. They take part, they talk, think, are happy and sad, engage others, defend own opinion (Dzintere, 2005, 76). The communication of children is ensured not only by 
the rich language, but also by the skill to choose means of expression appropriate for the concrete communication situation. Through games and through role-play in particular, children develop relationships that are observed between people at work, in the everyday life, during recreation, by observing norms of politeness, the rights and duties, the positive and the negative. That creates situations, in which a child learns the necessary norms of communication and learns to choose the linguistic means.

Adults have a wide array of opportunities to help children enrich their language by teaching the child to observe the surroundings, by talking to the child, reading aloud, telling stories, playing with it and thus encouraging the child's wish to explore the world around it, by inspiring the child to share its experience with others, teaching the child not to be ashamed of emotionality of expression, explaining the direct and indirect meanings of words, their nuances, the language specifics of poetry, folklore and regional language (Markus, 2003, 77). The successes of a small child in acquiring the native language depend largely on how skilful and tactful the adults will be in completion of these tasks. Kanepeija emphasizes that "the first and foremost means of speech development is the example of the adult language shown in continuous communication with a child" (Kanepejja, 2003, 53), as language cannot develop without communication. Mind develops through language, which can be stimulated by talking to a child frequently and by reading aloud to it. According to Daimonda, "reading aloud to a child does not just provide knowledge of the world outside of the everyday environments, but also broadens its vocabulary and understanding of words, stimulates its imagination. The more a child is exposed to hearing a language, the more its left hemisphere specializes in perception and production of words, and thus the thicker the cerebral cortex, which is linked to linguistics" (Daimonda, 1999, 145).

Studies show (Piaget, 1975) that many children gladly listen to fairy tales, stories and poems read aloud to them. Often novels, descriptions of nature and cognitions are also being read to children. A child develops the skills to listen carefully, to analyze and assess, to draw conclusions, to engage in a dialogue and to defend own opinion, as well as to persuade of its correctness or to accept the views of others. By listening to works of different genres, by retelling and interpreting them, children develop creative literary skills, enrich their emotional experience and their language. By supporting a child's interest in books, an adult may purposefully introduce the child to reading and writing skills already during the pre-school. It must be acknowledged that problems are often caused by language used either in folklore or in the work of earlier writers, which include words and forms that can no longer be found in contemporary language or which have acquired a different meaning, therefore pupils find help in dictionaries and other study means, but children, who do not yet know how to make use of reference books, have the adult as their primary counsellor. Through searching for an explanation of words 
in dictionaries and other sources together with the child, we may provide the child with an understanding of sources of information and develop their interest in dictionaries.

Up until school age a child's language is influenced by the family, friends and other people that the child recognizes as its authority. Family and parents are the first teachers, who develop and improve the child's language. At first they tell the story solely by using words that the child knows, they illustrate the action with various sounds and later on gradually add new words to the text (Rük,e-Dravin,a, 1995). Mother of the 5-year-old Jānis talks about ways of enriching a child's language: "I regularly buy and read books together with my son (one hour a day) and once a week we attend the library. I teach him different rhymes, ask questions about the stories we have read to initiate a dialogue. My son can retell the contents and compose stories by looking at the pictures in the book. By observing the advice of pedagogues for the upbringing of a child, I realized that frequent watching of television hinders the development of a child's creative imagination, verbal thinking and language, therefore my son may only watch one video and a cartoon film per week and children's television shows for one hour a day". From the age of three or even earlier the children of today become active television viewers, computer and Internet users. Pešele notes that television viewing for more than an our a day among children under the age of 7 reduces the time spent communicating with parents and peers (Pešele, 2005, 70). TV may become a resource of studies only if the parents watch it together with the child, discuss what they have seen, ask questions and help interpret the contents (Healy, 2003).

The most helpful thing in a wholesome development of a child and its becoming a rich personality is the attention and love of the parents. "The most important thing is whether the adult has been able to be happy while spending time with the child, has been able to find or has sought after common language with the child language of emotions and actions, which reflect the thought - you are small but I love you very much and I am delighted to be with you. Have mom and dad been able to come up with a "coo-coo" game and have they been able to understand the fears and joys of the child? Have they become more considerate with one another?" (Abramova, 2002, 435).

It has become common in our families to use different words and expressions when talking to children, to use a different style of talking. The same applies to the tendency of excessive use of diminutives. Parent survey data (conducted by RTTEMA students under the leadership of Kuzina in 2011, total number of respondents - 82) reveal that almost each family has developed its own lexicon, which is used in mutual communication and in communication with children: nicknames and pet names of family members, words taken over from a child's speech, use of words in a nontraditional way, twisted word forms, loanwords from other languages etc. Surveys characterize words that have their own history - words that are understood only 
by members of a single family and may seem funny or foolish for other listeners. Children actively engage in such language games, thus developing their creativity.

Unfortunately archaic upbringing techniques are common to this day. Parents in anger often call their children fools, idiots or blockheads, use offensive words and expressions: „Neplurini! Ko tu tur čammājies! Ko atkal lien! Lasies projām! Vai beigsi vēkškètt?"This phenomenon applies not only to the low-educated - indiscretion and lack of self-control is also common in intelligent families and even among teachers. Children are particularly sensitive to words, therefore parents and teachers should pay extra attention to their language and should take care of the flow of a child's language and development of a speech culture. A generally low level of culture usually is the reason for a poor speech culture.

Given that the majority of pre-school aged children attend pre-school education institutions, their speech may be largely influenced by a variety of people - teachers, nannies and other staff of pre-school education institutions, as well as other children with whom they spend the majority of the day.

Pre-school education institutions devote large attention to the development of children's language, linking it to the enrichment of vocabulary, strengthening pronunciation of sounds etc. (this is confirmed by our survey data).

In this regard the teacher Rūta ("Taurenītis"), who educates 5-year-olds, pays much attention to the enrichment of their vocabulary and therefore she writes: "The children in my groups like playing with words (for instance, for cats they make up words like - Pinkainitis, Muritis, Dusmigais etc.), they like fantasizing and building rhymes. In my work I use word games, which include exercises for strengthening, specifying and broadening the vocabulary, teaching the pronunciation of sounds, developing coherent speech of a child. It must be acknowledged that the meaning of many words (for example foreign words) is not always clear to them, therefore explanation of meaning is needed. I have observed that children are reluctant to use verbs and adjectives." By introducing her experience in the enrichment of children's vocabulary, the teacher Ārija ("Taurenītis") writes: "In the pre-school age period a child intuitively more or less understands and uses the words most commonly found in the everyday speech, including foreign words. In the kindergarten the vocabulary is acquired in accordance with a concrete programme, which is first and foremost orientated towards the selection of words that a child would need in communication with other people. His speech must be free of jargon, barbarisms and other words of non-literary language. The programme emphasizes the improvement of a child's vocabulary in accordance with the age of the children and the lecture topics, therefore I have access to folklore, fiction and game material, word exercises (for example, the task is to name the adjectives associated with the most commonly used words like a scarf, a spoon, a coat, a plate, for example, a scarf - soft, fluffy etc.; a spoon - small, clean etc.; a plate - large, shallow etc.; a coat black, warm etc.). For the development of language I make use of various everyday 
situations, games and other exercises, I teach children how to make use of various types of request, formulas for greeting someone and saying goodbye, as well as courtesy phrases (including manner of address), the use of tu (you - informal) and jūs (you - formal) in a conversation. During the lessons the attention of children is drawn towards different objects, their components, utility and characteristics. I conduct conversations about various images, I correct mistakes, pay close attention to folklore, children's literature. I teach how to compose short stories by using idioms and comparisons. Children learn to retell stories and to expressively recite poems, they develop the skill to perform in front of an audience. Children in my group are fond of games and puzzles."

It is understandable that the teacher develops the language of children while in kindergarten, and the work of the teacher depends on what his or her language is like (it must correspond to the norms of literary language and it must be expressive). The teacher must carefully, systematically and in a planned way work with the child's lexicon both during native language lessons (music, mathematics, etc.) and outside the lessons. In games and other lessons the children get to know different objects and phenomena, the teacher gives names of the objects that children see, while in lessons, during which children are introduced to folklore and fiction, the main source of a child's language enrichment is the folklore or fiction text.

An important task of parents and teachers is to introduce children to the riches of literary language in such sources of folklore that are understandable to children. There are, for instance, many folk songs, which reflect the lexicon of a particular dialect or archaic forms. Our folk songs is a source of pure, clear, beautifully sounding language. Primary school teachers acknowledge that children like learning folk songs about imitation of bird songs. Here are a few examples:

Kas dūdoja, kas dūdoja

Viña meža maliñā?

Tur dūdoja balodiši,

Savu māju taisīdami.
Trillu, trillu, cirulit, Kas tavā guzniñā?

Tiri mieži, kanepites,

Dzeltenais āboliņ̌š.
Nekūko dzeguzīt, Arumā zemītē, Kūko sila priedìtēs, Tur tev skaisti atskanēs.

Folktales and literary fairy tales introduce the child into an exciting and interesting world and richness of linguistic means of expression, they develop the child's fantasy, reasoning and language. It is important for the adults to draw the child's attention to the precise and figurative way an author characterizes the world in order to make the child strive for expressing itself in such a precise and figurative way.

Children very much like different puzzles, as they often have peculiar and witty questions or tasks that are captured in a metaphor or an allegory. Puzzles help to activate the logical thinking of a child, learning of new words and their meanings. If the children have broad knowledge of the surrounding world, if they perceive 
the surroundings figuratively and through comparisons, then solving puzzles is not difficult for them. Let us keep in mind that in Latvian folk pedagogy solving puzzles is a significant technique, through which children are introduced to the world and learn about the world through parables.

Fiction plays an important role in the growth of the future personality, as it helps the child acquire knowledge about the world and the life of adults and peers, about their thoughts, actions and efforts, to explore other cultures. The development of children's language is facilitated by the rich and figurative expression of poetry. In comparison to prose, it has more vivid creative means of expression. Contemporary children's poetry continues the traditions of folklore and classical poetry by revealing the beauty, diversity and complexity of the world through poetic means. Poetry (literature and art as such) has an important role in the process of discovering the world, particularly during childhood, when discovering things plays one of the most significant roles. In this regard teachers, who teach Latvian language and literature note that fiction texts that are included into the study books are rather complex, therefore they choose fiction with simple, easily understandable texts, which yet are rich in epithets, idioms and comparisons, because they enrich the language of children. Listening carefully to a language and fitting into the rich world of expression possibilities is something encouraged by the many poems written in the form of nursery rhymes and tongue-twisters. They teach children to listen and to pronounce, to recognize and detect coherence, to understand that each syllable and word has a place and significance as nothing in language is coincidental, but rather there are numerous possibilities for the use of language and its elements (Stikāne, 2000, 75).

In children's folklore (folk songs and other genres of folklore), children's literature (particularly in children's poetry) etc. there is a widespread of sound verbs (for instance, blèt, bubinät, maut, riet, vaukškèt, rïbèt, dunēt, grabèt, grandèt, sanēt, zumèt etc.). Compared to other languages (such as Russian, German or English), in Latvian one observes a particular richness of sound verbs (Freimane,1983,30). Apparently Latvians have had the need to give names to the most distanced nature noises and sound nuances, which explains the large diversity of sound verbs. By teaching the children to listen to the world, we may simultaneously develop their skills to give name to the sounds of this world, the way animals, birds, trees and flowers "talk", by paying attention to the extent of nuance, with which we can characterize various sounds both with words of exclamation and sound or onomatopoetic verbs and nouns, which are frequently found in spoken and written language (for instance, därdon, därdi, därdiens, grandon,a, grandiens, grands, rūkon, rūciens, tikškiens, blïkškis, blaukškis, tarkšksis, burkšksis, rejas, šalkon,a, šalka etc.). In poetry shorter words are used (for instance, grandi, därdi, rïba, duna etc.) as poetisms, which stand out due to their emotional nature. More characteristic to the conversational language are the more simple sound nouns, for instance, durvju čikston, motora rūkon, 
ratu rïbona (nouns with the suffix -ona signify a prolonged sound), zvēra rēciens, bungu rïbiens, ūdens šlakstiens (nouns with the suffix -iens signify a short sound). Furthermore, children often use exclamation words that serve as an expression of an as short as possible emotional reality, feelings, wishes or valuation (for instance, Krā!, Ak! Vai!, Škic! Pē! etc.). Expressions of greeting someone and saying goodbye traditionally are considered to be words of exclamation (for instance, Good evening!, Hello! Good night! etc.). These expressions are based on words or phrases with a vividly expressed wish. It is important for the child to learn to use comparisons (for instance, white as snow, soft as a fuzz-ball etc.), synonyms (for instance, to shine to glitter, to sparkle, to glisten etc.), idioms (for instance, saprast kädu no pusvärda (to be quick in the uptake), bèrt kā no grämatas (to talk someone's ear off), spicēt ausis (to sharpen one's ears), Dieva dāvana (a gift of God) etc.), foreign words in accordance with their meaning (for instance, vitamins, vital, to fantasize, a fantasy, a loggia, a balcony etc.), as these are an integral part of the everyday communication. By drawing the children's attention to the meaning of words, we adjust the child to thinking through what to say and how to say it, to make use of the words responsibly.

Diminutives are often used in different genres of folklore, children's literature, adult and children's language - both common names, such as dèlinšs (little son), lellite (little doll), klucìtis (little block), māmina (mommy) etc., and proper nouns - names of persons and animals, such as Aijina, Vilnitis, Annina, Muritis, Duksitis etc. In the everyday life proper names of children are often substituted by parents, relatives etc. with animal, flower names and names for other pleasant objects, for example balodìtis (little pigeon), cālìtis (little chicken), circenītis (little cricket), dūkulìtis (little kitten), jaukuminš̌ (sweety), odzin, (little berry), kazlēnin, š (little kid), priecin,š (little joy), bumbulitis, dārgumiňš, princesīte (little princess), vabolïte (little beetle), sirsnin,a (little heart), etc. Typical diminutives are the forms of address used in conversational language (for instance, māsin (little sister, vocative case), beernin (little child, vocative case), meitin (little daughter, vocative case) etc.) that express kindness and dearness to the addressed person. When used in a appropriate and fitting way, these words play an important role in the development of a child's emotional experience and speech behaviour. One must bear in mind that in a dialogue between a teacher and pupil a diminutive must be used with much consideration, in order to avoid a shift to the so called "caretaker-speech" or unnecessary intimacy.

In the multilingualism conditions of Latvia, teachers often have difficulty with children transferring unfitting words or phrases from other languages into Latvian, (for instance, kurtka (Russian for jacket), vot (Russian for here), forši (cool), okei (okay) etc.). Bilingualism and multilingualism is not a mechanical mixing of two or more languages, but rather coexistence of languages in a person's mind, equivalent skills of these languages. Therefore children must be provided an insight into the positive and negative sides of interference, thus stimulating the child to consciously 
differentiate the use of languages and not to merge elements of several languages into its speech or to substitute native language means of expression with such elements.

Survey and questionnaire results reveal that both parents and children acknowledge that the childhood stage is crucial in the development of a child's language skills and the adults have great responsibility for this process to be wholesome, interesting and exciting for the child.

\section{Conclusions}

1. To a developed child, who has acquired the basics of native language in the family, in the pre-school and the primary school, the further years of school serve as a an ongoing stage of language refinement, to ensure the ability to use own language as a good tool in all situations of the adult life. The richness of language is usually judged upon, by looking at the person's vocabulary.

2. Children's language is largely influenced by the language environment parents and other family members, staff of a pre-school educational institution, teachers, as well as films, television and radio programmes, theatre plays and books. In order for the child to fully acquire the native language, the language behaviour of adults as an example to the child, their language skills and level of language quality must be of importance.

3. In the pre-school age a child must acquire a vocabulary that would ensure full communication, would prepare the child for school, would help understand folklore and fiction, radio and television programmes, etc. Children's language develops through mutual games, various lessons (native language, drawing, mathematics etc.) as well as through extracurricular activities. During these pupils are purposefully being offered various language exercises, being provided an opportunity to express own observations and to describe different realia as precisely as possible, by engaging in various everyday situations through games and role-play

4. In order to enrich a child's language, in conversations with a child and during the study process it is important to create an opportunity to acquire the skill of incorporating synonyms, antonyms, idioms and comparisons into own speech and to understand the meaning of foreign words used in the everyday life etc. Given that nowadays the speech of children becomes more and more pragmatic, it is necessary to develop their skill to talk about various realia and events in a figurative way. Language encountered in folklore and fiction is characteristic for its epithets and various forms of trope: metaphors, personifications, allegories, and symbols. Therefore a skilfully selected material of Latvian folklore suitable for the child's age can facilitate the acquisition of figurative models of expression characteristic to the Latvian language. 
5. In child's language development large attention must be paid to the diminutive expression, as both the family, the pre-school the primary school, and the everyday adult-child communication are characterized by more active use of diminutives compared to regular communication. The child's education process should offer a didactic material that develops the child's experience in useful application of diminutives and an understanding of the variety of meanings and connotations that depend on each situation, as a single diminutive may express both sweetness, praise and criticism, contempt.

6. Working with words of exclamation and sound verbs or nouns that derive from these provides broad possibilities for enriching the child's vocabulary. Purposefully developed tasks and exercises can be completed while taking a walk or during a different lesson.

7. Given that some children exist in an environment of multiple languages, conversations with parents and the study process should pay attention to the positive and negative sides of language interference.

\section{References}

1. Dzintare, D, Stangaine, I. (2005) Rotala-bērna dzivesveids. [Children lifestyle - game]. Rìga: RaKa, 76. Ipp. (in Latvian).

2. Freiberga, I. (2006) Dzimtās valodas devalvācija un bērna attīstība pirmsskolas vecumā empîrisko vērojumu un teorētisko atziṇu aspektā. [Devaluation of the native language and child's development at his early stage on the aspect of empirical observations and theoretical conclusions]. In: Teorija praksei mūsdienu sabiedrïbas izglïtībā. III starpt. zin. konf. Zinātniskie raksti; Konferences ref. Rīga: RTTEMA, 133. Ipp.

3. Freimane, I. (1983) Latviešu valodas skanu verbi. [Sound verbs of Latvian language]. Rìga: LU, 30. Ipp. (in Latvian).

4. Graudiṇa, J, Lasmanis, A. (2004) Piecgadīgo un sešgadīgo bērnu sagatavošana skolai Latvijā. [Five and six years old childrens training for school in Latvia]. In: Teorija un prakse skolotāju izglïīibā II, Starpt. zin. konf. Rīga: RTTEMA, 163. Ipp.

5. Jurgena, I. (2002) Vispārīgā pedagoǵija. [General pedagogy]. Rīga: Izglītības soḷi, 77. Ipp. (in Latvian).

6. Kan,epāja, R. Lieǵeniece, D (2003) Es gribu iet skolā. [I want to go to school]. Rīga, 53. Ipp. (in Latvian).

7. Kuzina, V. (2005) Koptas valodas risinājumi normatīvajos avotos. [Quality of language in solutions of regulations and laws]. In: Valodu apguve: problēmas un perspektīva. IV Zin. rakstu krājums. Liepāja: LiePA, 50. Ipp.

8. Markus, D. (2006) Termini bērnu valodā. [Child language terminology]. In: Teorija praksei mūsdienu sabiedrības izglïīibā. III Starpt. zin. konf. Rīga: RPIVA, 309. Ipp. 
9. Markus, D. (2003) Bērnu valoda: no pirmā kliedziena lïdz pasakai. [Child language: From the first scream till fairytale]. Rīga: Rasa ABC, 77. Ipp. (in Latvian).

10. Pešele, S. (2005) Televīiija un valodas apguves problēmas bērniem līdz septinu gadu vecumam. [TV and language problems in children up to the age of seven]. In: Valodu apguve: problēmas un perspektīva. IV Zin. rakstu krājums. Liepāja: LiePA, 70. Ipp.

11. Rūḳe-Draviña, V. (1995) Pasaka par Sarkangalvïti vecāku un bērnu skatījumā. Apkärtnes ietekme valodas attīstïbä. [The Fairytale of the Little Red Riding Hood on the perspective of parents and children. Neighborhood influence on language development]. Rīga: RPIVA, 35. Ipp. (in Latvian).

12. Stikāne, I. (2000) Latviešu dzeja bērniem pasaules izziṇas procesā. [Latvian poetry for children in their cognitive process of the world]. In: Valoda un literatūra kultūras apritē. Zinātniskie raksti, 624. sēj. Rīga: LU, 75. Ipp.

13. Veidemane, R. (1987) Bet vārdā tik grūti ir tikt" (J.Peters). [lt is so hard to get in the meaning of the word]. In: Latviešu valodas kultūras jautājumi: 23. laidiens/sast. A.Rubīna Rīga: Avots, 45-49. Ipp.

14. Diamond, M., Hopson, J. (1999) Magic Trees of the Mind: How to Nurture Your Child's Intellioce, Creativity, and Healthy Emotions from Birth Trough Adolescence. USA, A.Plume Book, XIII, p. 145.

15. Healy, J.M. (28.12.2003.) Understanding TV's Effects on the Developing Brain. See online: http://www.aap.org./advocacy/chm98nws.htm

16. Абрамова Г.С. (2002) Возрастная психология. [Age Psychology]. Екатеринбург: Деловая книга, 435. Ipp. (in Russian).

\section{Prof. Dr. philol. Viktorija Kuzina}

Riga Teacher Training and Educational Management Academy

Address: Imantas 7. linija 1, Riga, LV-1083, Latvia

Phone: (+371) 26770085

E-mail: viktorija.kuzina@rpiva.Iv 